\title{
ZÁVISLÁ PRÁCE A JEJÍ PRÁVNÍ REGULACE NA POČÁTKU 21. STOLETÍ - VÝZVY A PERSPEKTIVY
}

\author{
JAKUB MORÁVEK*
}

\begin{abstract}
Dependent work and its legal regulation at the beginning of the 21st century challenges and perspectives

The paper is focused on some problematic aspects of labor law legislation. The author critically evaluates legal regulation and legislative proposals regulation of working hours, leave, termination of employment etc. The author also presents possible solutions. His reflextions is also based on an international comparison.
\end{abstract}

Keywords: labor law; working time; employment termination; leave; labor union

Klíčová slova: pracovní právo; pracovní doba; skončení pracovního poměru; odborové organizace; dovolená

DOI: $10.14712 / 23366478.2019 .6$

Opakovaně jsem poukazoval na to, že společné působení moderních technologií, životní úrovně západní civilizace a aktuálního životního stylu, stávající možnosti pracovního i volnočasového vyžití, hospodářské a sociální možnosti, krátce řečeno, vše, co můžeme souhrnně označit jako projevy moderní doby, působí postupnou erozi a rozpad některých tradičních společenských institutů a institucí, $\mathrm{k}$ jejichž ochraně (hodnotám, které prezentují) je vystavěna řada právních figur; tyto závěry byly formulovány po předložení argumentů, na kterých staví.

Dochází ke změně ve způsobu realizace určitých činností a $\mathrm{k}$ řadě souvisejících posunů. Okruh zasažených oblastí je přitom široký. Jde o tradiční rodinu, způsob života (uspořádání pracovního a soukromého času), ale i o způsoby výkonu práce. K tomu bylo řečeno, že některé ze stávajících schémat a institutů by bylo vhodné reformovat. At' již jde kupř́íkladu o právní úpravu rodičovské dovolené, či o samotné vymezení statusu zaměstnance, konkrétně o vytvoření nejméně dvou kategorií (statusů) zaměst-

\footnotetext{
* Autor působí na katedře pracovního práva a práva sociálního zabezpečení Právnické fakulty Univerzity Karlovy jako tajemník a odborný asistent. Je místopředsedou České společnosti pro pracovní právo a právo sociálního zabezpečení a advokátem v Praze. Př́íspěvek zohledňuje stav ke dni 1. ř́ijna 2018.
} 
nanců odvozených od charakteru vykonávané práce, či o dílčí doplnění stávajících figur, resp. o jejich posílení, v některých směrech (např. o formulaci práva na odpojení od zaměstnavatele atp.). ${ }^{1}$

Poukázání na problematické aspekty právní úpravy a zdůvodnění přesvědčení, že právní úprava není z nějakého důvodu dostatečná, je však pouze prvním krokem odborného diskurzu. Má-li být dosaženo pozitivního posunu, je nezbytné navázat formulováním možných řešení problematických bodů a předkládáním konstruktivně kritických argumentů ve vztahu k nim, kdy výsledkem takové debaty by mělo být nalezení nejlepšího řešení v kontextu celkové situace. Tento cíl si částečně klade předložený prííspěvek.

\section{RODIČOVSKÁ DOVOLENÁ2}

Z hlediska fyziologického, psychologického i sociálního vývoje a rozvoje dítěte se považuje za zásadní období od narození do jeho nejméně tř́ let věku. Pro budoucí biologický, psychologický i sociální vývoj dítěte a zprostředkovaně tedy i z obecného společenského hlediska je žádoucí, aby byl rodiči dítěte, bude-li mít zájem, poskytnut dostatečný časový prostor pro výchovu dítě v jeho raném věku a k prohloubení vztahů s ním. Již tradiční právní figurou, která má naplnit právě vymezený účel, je rodičovská dovolená. Rodičovská dovolená zakládá právo zaměstnance/zaměstnankyně po zaměstnavateli žádat k prohloubení péče o dítě poskytnutí pracovního volna. Oproti mateřské dovolené (ust. § $195 \mathrm{ZPr}$ ) rodičovská dovolená primárně nenavazuje na zdravotní stav člověka, který ji čerpá.

V návaznosti na individuální a celospolečenské zájmy prezentované účely institutu se s rodičovskou dovolenou, obdobně jako s mateřskou dovolenou, avšak v určitých pozicích v menší intenzitě, pojí i jiné právní důsledky, nežli je pouze poskytnutí pracovního volna (např́iklad jde o ochrannou dobu ve vztahu ke skončení pracovního poměru); tyto zpravidla souvisí se stabilitou pracovního poměru.

Právní úprava rodičovské dovolené má několik problematických aspektů.

Jedním z nich byla po určitou dobu otázka související s délkou čerpání rodičovské dovolené. Konkrétně, zda je v dispozici zaměstnance, který čerpá rodičovskou dovolenou, svým jednostranným jednáním skončit čerpání rodičovské dovolené a nastoupit

1 Zejména viz MORÁVEK, J. Prostředky právní ochrany a právní úprava pracovněprávních vztahů - problematické aspekty. In: DVOŘÁK, J. a kol. Soukromé právo 21. století. Praha: Wolters Kluwer. 2018. s. 332-346; Morávek, J. Prostředky moderní techniky a právní úprava pracovněprávních vztahů v České republice. In: BARANCOVÁ, H. - OLŠOVSKÁ, A. (eds.). Pracovné právo v digitálnej dobe. Olomouc: Leges. 2018; MORÁVEK, J. Sdílená ekonomika nejen z hlediska právní úpravy pracovněprávních vztahů. SOCIETAS ET IURISPRUDENTIA - Medzinárodný internetový vedecký časopis zameraný na právne otázky v interdisciplinárnych súvislostiach. Právnická fakulta Trnavské univerzity v Trnavě. Trnava. 2017. ročník V. svazek 4. s. $124-142$; MORÁVEK, J. Limity právního rádu a sociální stát v době moderních technologií. In: PICHRT, J. - BOHÁČ, R. - MORÁVEK, J. Sdilená ekonomika - sdilený právní problém? Praha: Wolters Kluwer. 2017; MORÁVEK, J. O vhodnosti a nevhodnosti novelizace zákoníku práce. In: GREGOROVÁ, M. (eds.). Pracovní právo 2016 - Zákoník práce v novelizaci, důchodová reforma v akci. Acta Universitatis Brunensis Iuridica, vol. 581, Masarykova univerzita, Brno, 2017, s. 20-54.

2 Vymezení problematických aspektů právní úpravy rodičovské dovolené vychází z př́ispěvku autora MORÁVEK, J. Ke změně některých sociálních paradigmat z hlediska právní úpravy pracovněprávních vztahů. In: KOLDINSKÁ, K. (ed.). Pocta Věre Stangové. Plzeň: Aleš Čeněk, 2018. 
zpět do zaměstnání před dnem, který původně označil jako den, do kterého bude rodičovskou dovolenou čerpat.

V současné době lze brát za nesporné, že bez dostatečně silného legitimního zájmu na straně zaměstnance obecně není prrípustné, nestanoví-li zákon výslovně jinak (viz ust. $\S 198 \mathrm{ZPr}$ ), aby zaměstnanec zaměstnavateli sdělil, že předčasně končí čerpání rodičovské dovolené a dostaví se do zaměstnání. Právo na předčasný návrat do zaměstnání zaměstnanci nesvědčí.

Jsou však i jiné problematické momenty a otázky, které souvisí s uvedeným v úvodní pasáži, tedy s erozí některých tradičních společenských institucí, a ve vztahu k nim prozatím uspokojivé řešení schází.

Kupříkladu, svědčí právo na rodičovskou dovolenou matce/otci (muži, jemuž svědčí domněnka otcovství dle předpisů občanského práva - viz ust. § 776 až § 784 ObčZ, př́íp. také NS 21 Cdo 3533/2009), jenž o dítě reálně nepečuje a ani pečovat objektivně nemůže (nebo nechce), jelikož je dítě například svěřeno do výlučné péče druhého $\mathrm{z}$ rodičů?

Zákoník práce v souvislosti s rodičovskou dovolenou předpokládá toliko rodičovství $\mathrm{k}$ dítěti do tř́ let věku a žádost o pracovní volno. Čistě jazykový výklad tudíž vede k závěru, že zaměstnanci/zaměstnankyni právo na pracovní volno svědčí; lze mít za to, že řada zaměstnavatelů by takovému zaměstnanci rodičovskou dovolenou poskytla, resp. že mu ji poskytla. Není však třeba dalekosáhle zdůvodňovat, proč by přiznání práva na rodičovskou dovolenou v tomto př́padě zcela popíralo smysl a účel institutu.

I za stávající právní úpravy je situace řešitelná následovně. I přes to si však právní jistota určitou korekci právní úpravy žádá.

$\mathrm{S}$ ohledem na povahu důsledků, které plynou z žádosti zaměstnance nebo zaměstnankyně o čerpání rodičovské dovolené (poskytnutí pracovního volna z titulu rodičovské dovolené), je žádost právním jednáním. Žádost tedy musí naplňovat všechny obecné náležitosti právního jednání, jak plynou zejména z předpisů práva občanského (poctivost, srozumitelnost, určitost atp. - viz zejména ust. $\S 6$ až 8 a ust. $\S 545$ an. ObčZ). Žádost takového rodiče, která by byla zjevným zneužitím práva a jednáním mimo smysl a účel právní normy (srov. mj. NS ČR 21 Cdo 624/2001), by na platné právní jednání aspirovat zjevně nemohla.

Obdobná situace může nastat i z druhé strany. Konkrétně např́íklad muži, kterému nesvědčí domněnka otcovství, nicméně žije s matkou dítěte ve společné domácnosti a s ohledem na předpoklad budoucího společného života má skutečný zájem na prohlubování vztahu s (byt' nevlastním) dítětem a o péči o něj, právo na rodičovskou dovolenou nesvědčí, byt' by mu podle smyslu a účelu institutu svědčit mělo. Tento nedostatek však již výkladem odstranit nelze.

Z uvedeného se podává, že by bylo vhodné kriticky zhodnotit instituty obdobné rodičovské dovolené a př́padně provést dílčí korekce tak, aby (převedeno na rodičovskou dovolenou) rodiči, který pečovat o dítě nechce, či z objektivního důvodu, který nelegitimizuje opačný záměr, o dítě pečovat nemůže, právo nesvědčilo. Naopak, pokud je zde člověk, který sice není rodičem dítěte, ale žije s ním ve společné domácnosti a má opravdový zájem o dítě pečovat, dle smyslu a účelu institutu by mu právo na pracovní volno svědčit mělo, stejně jako související pozitivní právní důsledky (ochranná doba atp.). 
Pozitivně lze v tomto směru vnímat právní úpravu dlouhodobého ošetřovného, jak je obsažena v zákoně č. 187/2006 Sb., o nemocenském pojištění. Konkrétně jde-li o možnost péče ze strany druha/družky žijící s ošetřovanou osobou v domácnosti - ust. § 41a odst. 4 zákona č. 187/2006 Sb. zavádí podmínku, že za družku/druha se považuje ten, kdo s dotčeným člověkem má alespoň tři měsíce shodné místo trvalého pobytu.

Obdobné pojetí naznačené podoby rodičovské dovolené de lege ferenda, tedy př́ípad, kdy může rodičovskou dovolenou čerpat jiná osoba nežli rodič dítěte, která však dítě současně neosvojila, za podmínky, že s ním žije ve společného domácnosti a pečuje o něj, lze ostatně vysledovat i v zahraničních právních úpravách, například ve Švédském zákoně č. 1995:584 SFS o rodičovské dovolené, ${ }^{3}$ který vedle rodičovské dovolené (pracovního volna určeného $\mathrm{k}$ péči o dítě a prohloubení vztahů s ním v době po jeho narození) reguluje i materii, kterou bychom v právním řádu České republiky našli v ust. $\S 239$ an. ZPr, tj. právní úpravu zvláštních pracovních podmínek těhotných zaměstnankyn̆, zaměstnankyň matek, zaměstnanců a zaměstnankyň pečujících o dítě.

Zákon přiznává shodná práva, nejen právo na rodičovskou dovolenou, ale i další práva založená jmenovaným zákonem rodičům dítěte:

(a) zaměstnanci, který není rodičem dítěte, avšak je jeho opatrovníkem, pokud se o dítě stará (např́ílad je-li v péči prarodiče),

(b) zaměstnanci, který má dítě v trvalé péči (pěstounovi dítěte), pečuje-li o dítě ve své rodinné domácnosti, či

(c) zaměstnanci, který trvale žije s rodičem dítěte za předpokladu, že zaměstnanec je nebo byl manželem rodiče či má nebo měl dítě $s$ rodičem dítěte.

Z hlediska nastavení tuzemské regulace dále není bez zajímavosti, že právní úprava rodičovské dovolené ve Švédsku je provázána s rodičovskou dávkou v rámci systému sociálního zabezpečení, konkrétně podle zákona č. 2014:948 SFS o sociálním pojištění.

Zákon (ZoRD) zná šest typizovaných případů pracovního volna poskytovaného $\mathrm{v}$ souvislosti s péćí o dítě $\mathrm{v}$ době před a po jeho narození. U řady $\mathrm{z}$ nich lze najít paralelu v rámci zdejší právní úpravy.

\section{A) MATEŘSKÁ DOVOLENÁ (§ 4 ZORD)}

Jedná se o pracovní volno určené pro zaměstnankyni $\mathrm{v}$ době před a po narození dítěte. Pracovní volno se poskytuje v rozsahu plného pracovního úvazku. Z hlediska právního rádu České republiky se jedná o institut srovnatelný s mateřskou dovolenou ve smyslu ust. § 195 ZPr. V určité omezené míře, jde-li o navazující instituty, se právní úprava použije i pro dobu kojení.

Pracovní volno se poskytuje $\mathrm{v}$ délce sedmi týdnů před a sedmi týdnů po narození dítěte. Dva týdny před a po porodu musí být vyčerpány povinně. To neplatí, byla-li před narozením dítěte vyčerpána kratší doba proto, že porod nastal dříve (či z jiného obdobného důvodu).

3 Dále jen $Z o R D$. 


\section{B) PLNÁ (RODIČOVSKÁ DOVOLENÁ) DOVOLENÁ/PRACOVNÍ VOLNO \\ (S RODIČOVSKOU DÁVKOU PODLE ZÁKONA Č. 2014:948 SFS O SOCIÁLNÍM POJIŠTĚNÍ)}

Jedná se o pracovní volno, které se poskytuje v rozsahu plného pracovního úvazku rodiči do 18 měsíců věku dítěte a případně i po této době, má-li zaměstnanec právo na plnou rodičovskou dávku podle zákona č. 2014: 948 SFS o sociálním pojištění; naprríklad při osvojení/převzetí dítěte do péče nahrazující péči rodičů. Pracovní volno lze nicméně i v těchto případech čerpat nejdéle do 8 let věku dítěte nebo do skončení prvého roku školní docházky dítěte podle toho, co nastalo dříve.

Z hlediska právního řádu České republiky se jedná o institut srovnatelný v základu s rodičovskou dovolenou ve smyslu ust. $§ 196 \mathrm{ZPr}$, resp. př́padně s mateřskou a rodičovskou dovolenou při převzetí dítěte do péče ve smyslu ust. § 197 ZPr.

\section{C) ČÁSTEČNÁ RODIČOVSKÁ DOVOLENÁ/PRACOVNÍ VOLNO S RODIČOVSKOU DÁVKOU (§ 6 ZORD)}

Pracovní volno se poskytuje pouze v části pracovního úvazku $(3 / 4,1 / 2$, $1 / 4,1 / 8)$ v návaznosti na to, v jaké míre se poskytuje rodičovská dávka ve smyslu ust. $\S 12$ zákona č. 2014: 948 SFS o sociálním pojištění.

\section{D) ČÁSTEČNÁ RODIČOVSKÁ DOVOLENÁ/PRACOVNÍ VOLNO BEZ RODIČOVSKÉ DÁVKY (§ 7 ZORD)}

Jedná se o zkrácení pracovního úvazku až o 1/4. Zkrácení je možné nejdéle do 8 let věku dítěte. $Z$ hlediska právního řádu České republiky lze institut přirovnat k právní úpravě obsažené v ust. § $241 \mathrm{ZPr}$, tj. k úpravě zkrácení/změně rozsahu pracovního úvazku (nebo rozvržení pracovní doby) k žádosti zaměstnance pečujícího o dítě do 8 let věku, resp. 15 let věku, jde-li o osamělého zaměstnance.

\section{E) RODIČOVSKÁ DOVOLENÁ/PRACOVNÍ VOLNO S DOČASNÝM RODIČOVSKÝM PŘÍSPĚVKEM (§ 8)}

Jedná se o pracovní volno na nezbytně nutnou dobu, kdy rodič musí pečovat o dítě např́iklad z důvodu nemoci. $Z$ hlediska právního řádu České republiky by bylo možné přirovnat tuto situaci k překážkám v práci formulovaným v ust. $\S 191$ ZPr, kdy se poskytuje pracovní volno v souvislosti s nezbytnou péčí o dítě, konkrétně: ,,po dobu ošetrováni dítěte mladšího než 10 let nebo jiného člena domácnosti v př́padech podle § 39 zákona o nemocenském pojištění a po dobu péče o ditě mladši než 10 let $z$ di̊vodi̊ stanovených $v$ \& 39 zákona o nemocenském pojištění nebo z důvodu, kdy se fyzická osoba, která o ditě jinak pečuje, podrobila vyšetřeni nebo ošetření u poskytovatele zdravotnich služeb, které nebylo možno zabezpečit mimo pracovni dobu zaměstnance, a proto nemůže o dítě pečovat." 
Pracovní volno se poskytuje v rozsahu plného pracovního úvazku či v jeho polovině. $V$ tomto prrípadě je pracovní volno navázáno na nárok rodiče na příspěvek na východu podle $\S 8$ zákona č. 2008: 307 o obecním příspěvku na východu dětí.

Inspirativní však může být Švédská úprava i v jiných aspektech.

Dle ust. $\S 10$ ZoRD lze rodičovskou dovolenou čerpat po částech. $\mathrm{V}$ rámci kalendářního roku svědčí zaměstnanci právo třikrát jednostranně změnit své rozhodnutí stran čerpání x nečerpání pracovního volna (rodičovské dovolené). Pokud čerpání (rozhodnutí) přesáhne do následujícího kalendářního roku, započítá se čerpání pouze do roku, ve kterém bylo čerpání zahájeno. Zaměstnanec, pokud jde pouze o částečnou dovolenou (zkrácení úvazku), může rodičovskou dovolenou čerpat pouze v některé dny v týdnu např́íklad v pondělí a ve středu otec, $v$ úterý, ve čtvrtek a v pátek matka; v tomto jde tedy o právní úpravu v principu shodnou s ust. § $241 \mathrm{ZPr}$, na nějž již bylo poukazováno shora.

Zákon preferuje dohodu. Vedle toho nicméně zaměstnanci přiznává právo na určení čerpání, stejně jako právo na změnu čerpání či právo na předčasný návrat do zaměstnání. Zaměstnavatel nemusí zaměstnanci $\mathrm{k}$ žádosti o předčasný návrat vyhovět pouze tehdy, jsou-li pro to vážné provozní důvody (zájem zaměstnavatele převáží nad zájmem zaměstnance).

Čerpání, příp. změna se oznamuje nejméně dva měsíce předem. Není-li to možné, je předepsána lhůta k oznámení bez zbytečného odkladu. Výjimkou je pracovní volno ve smyslu písm. e) shora, kde činí lhůta jeden týden, nejde-li o nemoc nebo jiný důvod čerpání pracovního volna, kde lhůta k předchozímu oznámení předepsána není a volno lze čerpat bezprostředně.

Rozhodnutí zaměstnance o předčasném návratu do zaměstnání zaměstnanec zaměstnavateli oznamuje bez zbytečného odkladu. Zaměstnavateli svědčí právo návrat zaměstnance oddálit až o 1 měsíc od oznámeného data návratu do zaměstnání, pokud se jedná o př́ípad, kdy bylo pracovní volno podle původního oznámení zaměstnance čerpáno $\mathrm{v}$ rozsahu jednoho měsíce nebo déle.

Dohoda zaměstnance a zaměstnavatele, která by zkracovala zaměstnance na jeho právech, je stíhána neplatností.

Odchýlení se od zákona je možné prostřednictvím kolektivní smlouvy, jde-li např́íklad o úpravu oznámení dovolené ve smyslu ust. § 13 ZoRD, doby, kdy má zaměstnanec povinnost oznámit návrat do zaměstnání ve smyslu ust. § 15 odst. 2 ZoRD, či doby, po kterou je zaměstnavatel oprávněn oddálit návrat zaměstnance do zaměstnání ve smyslu $\S 15$ odst. 3 ZoRD. 


\section{VYBRANÉ OTÁZKY PRACOVNÍ DOBY, DOBY ODPOČINKU A DOVOLENÉ}

Právní úpravu pracovní doby, doby odpočinku a dovolené není důvod v generální rovině hodnotit negativně. Uvedené však neznamená, že neexistují problematické momenty. Ne všechny však jsou důsledkem legislativní činnosti. Některé plynou spíše z nevhodně zaužívané praxe a z nesprávné interpretace zákonodárství. Za všechny lze poukázat na dva príklady.

Jednak na zákonem předepsanou dobu (ust. § $84 \mathrm{ZPr}$ ) pro seznámení zaměstnance s rozvrhem směn, kdy slova „nedohodnou-li se jinak“ jsou aktuálně interpretována tak, že možná je i dohoda na kratší době pro seznámení, než je zákonem předepsaná doba 2 týdnů, resp. 1 týdne, a dále o právní úpravu konta pracovní doby, kdy právní úprava nijak nereflektuje vůli dotčeného zaměstnance.

Je částečně překvapující, že jak dřívější návrh novely zákoníku práce (tisk 903/0 viz shora), tak stávající podoba připravované novely zákoníku práce ${ }^{4}$ bud'to na tyto problematické momenty vůbec necílí, nebo pokud ano, tak ze špatné strany. Vedle toho se naopak věnuje změně institutů, které problematické nejsou a novelizaci se tudíž nežádají, jako je právní úprava dovolené.

$\mathrm{V}$ této souvislosti lze jak k navržené změně ust. $\S 84 \mathrm{ZPr}$, tak k nově navrhované podobě právní úpravy dovolené $\mathrm{v}$ krátkosti poukázat na dříve uvedené 5 a již nanesené argumenty doplnit o související úvahy, včetně námětů de lege ferenda vyplývajících z právních řádů jiných zemí.

\subsection{DOBA PRO SEZNÁMENÍ ZAMĚSTNANCE S ROZVRHEM SMĚN A ROZVRŽENÍ PRACOVNÍ DOBY}

Stávající právní úpravu ust. § $84 \mathrm{ZPr}$ (předepsanou dobu dvou týdnů) lze považovat za minimální $\mathrm{k}$ tomu, aby člověk dokázal racionálně plánovat svůj soukromý a rodinný život - dokázal pro sebe a svou rodinu určit, který čas bude věnován práci, a který bude věnován společným aktivitám, naplánoval si soukromé záležitosti běžného života, jako je návštěva zubního lékaře atp. Situace, kdy zaměstnanec neví, zda bude či nebude povolán $\mathrm{k}$ výkonu práce ze dne na den, která je dnes $\mathrm{v}$ aplikační praxi pravidlem, nebot' je hojně využívána (nesprávně) dovozená dispozitivnost právní úpravy ve směru k možnému zkrácení zákonné lhůty, a to až na řády dnů či hodin, nedává žádnou jistotu pro zaměstnance a ani jeho rodinu. ${ }^{6}$

4 Viz $<$ https://apps.odok.cz/veklep-detail?pid=ALBSB3QAMAG7>.

$5 \mathrm{~K}$ tomuto srov. taktéž MORÁVEK, J. Seznámení zaměstnance s rozvržením pracovní doby v perspektivách času. In: HROMADA, M. (eds.). Pocta Jarmile Pavlátové k 85. narozeninám. Plzeň: Západočeská univerzita v Plzni, 2018, s. 31-41, nebo MORÁVEK, J. O vhodnosti a nevhodnosti novelizace zákoníku práce. In: GREGOROVÁ, Z. (eds.). Pracovní právo 2016 - Zákoník práce v novelizaci, důchodová reforma v akci. Acta Universitatis Brunensis Iuridica. vol 581, Masarykova univerzita, Brno, 2017, s. 20-54.

6 A to hovoříme o standardní rodině a rodinném životě. Ještě závažnější by situace byla v momentě, kdy je kupř́íkladu dítě ve stř́idavé péči. Argumentace přesčasovou prací v této souvislosti není na místě. Jednak je přesčasová práce vázána na podmínku, že může být konána jen výjimečně. Jednak je přesčasová práce časově omezena. Částečně relevantní je v tomto směru toliko právní úprava zvláštních pracovních podmínek některých zaměstnancủ, jak je obsažena primárně v ust. § 237 an. ZPr. 
Stávající právní úprava obsažená v ust. § 84 ZPr navazuje na úpravu ust. § 85 zákona č. 65/1965 Sb., zákoník práce. ${ }^{7}$ Rozdíl úprav spočívá pouze $\mathrm{v}$ dílčím odlišném věcném dosahu, když ZP65 povinnost v časovém předstihu zaměstnance seznámit s rozvrhem pracovní doby vztahoval pouze $\mathrm{k}$ pracovní době, která byla rozvrhována nerovnoměrně, kdežto podle stávající právní úpravy dopadá povinnost na všechny př́ípady.

Stran účelu právní úpravy důvodová zpráva ${ }^{8} \mathrm{k}$ ust. $\S 84 \mathrm{ZPr}$ nic konkrétního nestanoví. Pouze omezeně je $\mathrm{v}$ tomto směru relevantní odkaz $\mathrm{v}$ důvodové zprávě na ust. § 13 ZPr v původním znění. Ustanovení § 13 ZPr obsahovalo určité základní principy a zásady, které lze dnes částečně nalézt v ust. § 346b an. ZPr. Dle ust. § 13 odst. 3 ZPr pak zaměstnanec měl mj. právo na rozvržení pracovní doby před zahájením práce, přičemž však v kontextu důvodové zprávy měla být dikce určující primárně pro rozlišení odlišné povahy dohod o pracích konaných mimo pracovní poměr a pracovního poměru, kdy v př́ípadě dohod povinnost rozvrhnout pracovní dobu předepsána není.

Jelikož je jádro právní úpravy v ZPr a v ZP65 totožné, lze se při hledání účelu právní regulace obrátit k zákonu č. 155/2000 Sb., kterým se mění zákon č. 65/1965 Sb., zákoník práce, ve znění pozdějších předpisů, a některé další zákony, jímž bylo předmětné ustanovení do zákonné dikce ZP65 vtěleno. V důvodové zprávě ${ }^{9}$ se ke změně uvádí: „Nově se zar̆azuje povinnost zaměstnavatele stanovit pisemně rozvrh nerovnomèrného rozvržení pracovní doby, což má ve svém důsledku zajistit ochranu oprávněných zájmů zaměstnanců i zaměstnavatelü.“

Vedle toho, a to je neméně důležité, lze právní úpravu ust. § 85 odst. 3 ZP65, resp. $\S 84$ ZPr brát z jistého hlediska za reakci na směrnici Evropského parlamentu a Rady 2003/88/ES ze dne 4. listopadu 2003 o některých aspektech úpravy pracovní doby. Byt' ust. $§ 84 \mathrm{ZPr}$ nefiguruje $v$ ust. $§ 363 \mathrm{ZPr}$ a nejde tedy o transpozici v pravém smyslu slova, lze se kvůli nedostatečné deklaraci účelu regulace ze strany zákonodárce klonit k závěru, že jmenované ustanovení, stejně jako ust. § 85 ZP65, by mělo být nahlíženo a aplikováno také v kontextu výkladového cíle plynoucího z recitálu č. 11 směrnice 2003/88/ES, dle kterého: „Organizace práce podle určitého rozvrhu musí prihližet $k$ obecné zásadě, že práce musí být prizizpơsobena člověku.“"

Bez významu dále není, že před novelizací ZP65 žádnou konkrétní povinnost $\mathrm{v}$ určitém časovém předstihu zaměstnance informovat o rozvržení pracovní doby do směn nepředepisoval. Právní úprava stavěla dle všeho na shodném schématu jako smlouva služební a smlouva o dílo (ust. § 1151 an. o.z.o), resp. až do přijetí císařského nařízení č. 96 ř. z. ze dne 19. března 1916 smlouva námezdní. $Z$ dobové judikatury (např. NS Rv I 654/39) stejně jako z dobové literatury plyne, že „délka denního zaměstnání ř́dí se úmluvou (ovšem v mezích zákonných) a, neni-li jí, dlužno uznati podle mistního zvyku na dobu přiměrenou." 10

7 Dále jen ZP65.

8 Parlament České republiky, Poslanecká sněmovna, 2002-2006, tisk 1153/0.

9 Parlament České republiky, Poslanecká sněmovna 1998-2002. tisk 484/0.

10 ROUČEK, F. - SEDLÁČEK, F. a kol. Komentáŕ k československému obecnému zákoníku občanskému a občanské právo platné na Slovensku a v Podkarpatské Rusi. Díl. V. §§ 1090-1341, Praha: Wolters Kluwer. 2013. s. 248. 
Při nedostatečně deklarovaném cíli právní regulace nezbývá, než obecný účel ,zajistit ochranu oprávněných zájmů zaměstnanců i zaměstnavatelü“ a tedy i právní úpravu samu, vnímat a číst prizmatem interpretačního předpokladu racionálního zákonodárce; zejména s přihlédnutím $\mathrm{k}$ tomu, že žádná konkrétní povinnost $\mathrm{v}$ předepsaném časovém předstihu zaměstnance informovat o rozvržení pracovní doby do směn dříve stanovena nebyla, a dále s ohledem na technologické změny a změny ve způsobu výkonu práce, které technologické změny (rozvoj komunikačních technologií, elektronických médií a výpočetní techniky, které umožňují neustálé spojení zaměstnance se zaměstnavatelem, a stírají tak postupně hranici mezi časem vyhrazeným práci a časem vyhrazeným pro soukromý a rodinný život) v určitých segmentech hospodářství přinesly, ale i s ohledem na strukturu převážné části tuzemských podnikatelů/zaměstnavatelů.

Náhled právní úpravy optikou racionálního zákonodárce vede k následujícím závěrům.

Tradiční tovární nebo obdobná průmyslová výroba je zpravidla realizována prostřednictvím zaměstnanců se směnným rozvržením pracovní doby. Vytvořit směnný rozvrh pracovní doby ve velkém nepřetržitém provozu pro řádově desítky, resp. stovky či větši počet zaměstnanců vyžaduje relativně náročné a složité plánování a značné úsilí. Pracovní doba tudíž bývá rozvrhována na týdny či měsíce dopředu a je tak jen málo pravděpodobná častá a překotná změna rozvržení pracovní doby. Jinak je tomu zpravidla v oblasti služeb, v malých provozech a u drobných podnikatelů. Zde je žádoucí flexibilita, přičemž tato potřeba bývá ještě dále podpořena, jedná-li se o kreativní činnost, působení a uplatňování moderních technologií v pracovním procesu.

Pokud schází odpovídající právní figury umožňující flexibilní výkon práce (práce na zavolanou, odpovídající pravidla pro práci mimo pracoviště zaměstnavatele atp.), vedou takové okolnosti přirozeně $\mathrm{k}$ tendenci zaměstnavatelů, je-li možné si ujednat časový předstih, ve kterém bude zaměstnanci muset být oznámeno rozvržení pracovní doby do směn, nezbytnou dobu pro seznámení co možná nejvíce zkrátit. Př́lišs krátká doba pro seznámení se s rozvrhem směn nebo s jeho změnou však má pro zaměstnance (jeho soukromý a rodinný život a pro jeho rodinu vůbec) shora popsané negativní důsledky.

Za těchto okolností je přirozeným projevem úvahy racionálního zákonodárce, který zohledňuje všechny zmíněné aspekty a dotčené zájmy a hodnoty (základní práva a svobody), stanovit minimální dobu, ve které zaměstnanec musí být seznámen s rozvrhem směn nebo s jeho změnou. ${ }^{11}$ Výsledek vážení došel pozitivního vyjádření v ust. $§ 85$ ZP65 a v ust. § $84 \mathrm{ZPr}$.

Za těchto předpokladů se pak nezdá být správný závěr dovozovaný v odborné literatuře, ${ }^{12}$ že ust. $\S 84$ ZPr je dispozitivní v obou směrech, tj. umožňuje dohodu zaměstnance a zaměstnavatele o prodloužení předepsané doby stejně jako o jejím zkrácení; z povahy věci bývá $v$ aplikační praxi doba delší dohadována zcela výjimečně, naopak

11 Stejné platí pro př́ípady, kdy po vyhodnocení situace je učiněn závěr, že dřívější opatření dotýkající se pouze nerovnoměrného rozvržení pracovní doby, není dostatečné, a je třeba přistoupit k jeho rozšsiŕení i na rovnoměrné rozvržení pracovní doby.

12 Viz např́iklad ŠTEFKO, M. In: BĚLINA, M. - DRÁPAL, L. a kol. Zákoník práce. Velký komentářr. 2. vyd. Praha: C. H. Beck. 2015. s. 532. 
kratší doba je dohadována pravidelně a není výjimečné, aby doba pro seznámení s rozvrhem směn či s jeho změnou byla ujednána v rozsahu jednoho dne, nebo dokonce v řádech hodin (je samozřejmě otázka, zda lze hovořit o dohodě v momentě, kdy pracovní smlouva má de facto povahu smlouvy adhezní).

Krátce řečeno, vycházeje z Ústavním soudem České republiky opakovaně potvrzené teze (viz např. ÚS ČR ve věci sp. zn. Pl. ÚS 33/97), jež stojí v základu demokratického právního státu, a která našla své pozitivní vyjádření pro oblast soukromého práva v ust. $\S 2$ odst. 1 ObčZ ${ }^{13}$, a s přihlédnutím k zásadě ochrany slabší strany, resp. zvláštní zákonné ochraně postavení zaměstnance, lze dospět k závěru, že od ust. § 84 ZPr by mělo být možné se platně odchýlit pouze ve prospěch zaměstnance, tedy tak, že se dohodou zaměstnance a zaměstnavatele doba prodlouží a nikoli zkrátí.

V uplynulém volebním období Poslanecké sněmovny Parlamentu České republiky byla navržena novelizace ust. $§ 84$ ZPr, která byla prezentována jako kompromis mezi návrhem zástupců zaměstnavatelů a návrhem zástupců zaměstnanců. Konkrétně se navrhovalo ust. $\S 84$ ZPr doplnit takto: „Zaměstnavatel je povinen vypracovat písemný rozvrh týdenní pracovní doby a seznámit s ním nebo s jeho změnou zaměstnance nejpozději 2 týdny a v připadě konta pracovni doby 1 týden před začátkem období, na něž je pracovní doba rozvržena, pokud se nedohodne se zaměstnancem na jiné době seznámení, která však nesmí být kratši než 2 dny. "14 Dle důvodové zprávy se jedná „o věcnou změnu týkající se pravidel rozvrhování pracovní doby zaměstnancưm. Předkladatel $v$ rámci pravidel o písemném rozvrhování týdenni pracovní doby zaměstnanci usiluje o to, aby ani v př́padě dohody zaměstnavatele se zaméstnancem na jiné kratši době seznámení s rozvrhem týdenní pracovni doby, než jsou zákonné 2 týdny předem, nemohlo docházet $k$ seznámení s rozvrhem či jeho změnou bezprostředně před výkonem práce, tj. k práci na zavolanou. Návrh je odrazem kompromisního řě̌ení (pozn. autora návrhu zástupců zaměstnavatelů 1 den předem a návrhu zástupců zaměstnanců 3 dny předem) a stanovuje, že zaměstnanec musí být seznámen s rozvrhem pracovní doby či s jeho změnou minimálně 2 dny předem. Jde o snahu o vylepšení podmínek slad'ování rodinného a pracovního života a zamezeni prekérnosti práce na zavolanou. "Novelizační bod shodného znění je začleněn i do aktuálně připravované novely zákoníku práce. ${ }^{15}$

Ze shora uvedeného se však podává, že pokud by měla být provedena novelizace, pak tak, aby rozhodná část zákonné dikce zněla zhruba následovně: „Zaměstnavatel je povinen vypracovat písemný rozvrh týdenní pracovní doby a seznámit s ním nebo s jeho změnou zaměstnance nejpozději 2 týdny a v př́padě konta pracovní doby 1 týden pred začátkem období, na něž je pracovni doba rozvržena, pokud se nedohodne se zaměstnancem na jiné delší době seznámeni. “Výjimku z tohoto pravidla si lze představit v mimořádných situacích (živelní událost atp.) nebo po dohodě s odborovou organizací, bude-li to s ohledem na povahu provozu nezbytné.

13 Ust. § 2 odst. 1 ObčZ: „Každé ustanovení soukromého práva lze vykládat jenom ve shodě s Listinou základnich práv a svobod a ústavním pořádkem vůbec, se zásadami, na nichž spočivá tento zákon, jakož is trvalým žretelem $k$ hodnotám, které se tím chrání. Rozejde-li se výklad jednotlivého ustanovení pouze podle jeho slov s tímto př́kazem, musí mu ustoupit."

14 Parlament České republiky. Poslanecká sněmovna 2013-2017. tisk. 903/0.

$15 \mathrm{Viz}<\mathrm{https}$ ://apps.odok.cz/veklep-detail?pid=ALBSB3QAMAG7>. 
Takový model by nebyl novinkou. Zná jej např́klad švédský zákon 1982: 673 SFS o pracovní době. ${ }^{16}$ Dle ust. $\S 12$ ZoPD je mj. zaměstnavatel povinen zaměstnanci vykonávajícímu práci v pracovním poměru na dobu neurčitou rozvrhovat pracovní dobu, resp. seznámit ho se změnou organizace pracovní doby, nejméně 2 týdny předem. Kratší doba je možná, žádá-li si to povaha vykonávané práce nebo mimořádná událost. Co je v tomto právním prostředí typické, od základní zákonné úpravy je možné se odchýlit prostřednictvím kolektivní smlouvy.

V úvahách úvah o novelizaci zákoníku práce ve vztahu ke stávající právní úpravě pracovní doby a doby odpočinku nicméně nabízí Švédská právní úprava i několik dalších podnětů.

S ohledem na shodný podklad $v$ evropské regulaci (směrnici 2003/88/ES) je právní úprava $\mathrm{v}$ řadě aspektů přirozeně obdobná, byt' $\mathrm{i}$ transponovaná úprava je dílčím způsobem doplněná odlišně. Kupř́kladu (ust. § 13 ZoPD) evropský standard denního odpočinku v minimálním rozsahu 11 hodin v rámci 24 hodin po sobě jdoucích by měl být dle švédské právní úpravy nařizován, pokud možno tak, aby byl čerpán mezi 24:00 a 5:00. Přestávka v práci (dle zdejší terminologie přestávka na jídlo a oddech) zaměstnanci náleží (ust. § 15 ZoPD) nejdéle po 5 hodinách nepřetržitého výkonu práce. Délka přestávky prritom není upravena. Stanoví se pouze, že počet přestávek, délka jejich trvání a organizace musí být uspokojivé z hlediska podmínek výkonu práce. ${ }^{17}$

V návaznosti na nedávno vedený odborný diskurs k otázce výkladu a aplikace zdejší právní úpravy doby nepřetržitého odpočinku v týdnu se dále nabízí poukázat na ust. $\S 14$ ZoPD. Dle odkazovaného ustanovení zaměstnanci náleží nepřetržitý odpočinek v rozsahu 36 hodin za každých 7 dní. ${ }^{18}$

Dále se nabízí zmínit právní úpravu přesčasové práce obsaženou v ust. § 7 an. ZoPD. Dle odkazovaných ustanovení je přesčasová práce možná při zvýšené potřebě počtu pracovních hodin (z provozních nebo z jiných obdobných důvodů) nejvýše však v rozsahu 200 hodin za kalendářní rok. Ust. § 8a ZoPD dále zná tzv. dodatečné (extra) přesčasové hodiny v rozsahu až 150 hodin za kalendární rok s tím, že extra přesčas v rámci tohoto limitu je možné zaměstnanci nařídit jedině, jsou-li pro to vážné důvody a není-li možné potřebu pracovní síly pokrýt jiným rozumným opatřením. V úhrnu je tudíž možné dosáhnout až 350 hodin přesčasové práce za rok s tím, že maximální rozsah přesčasové práce za 4 týdny nesmí přesáhnout 48 hodin, resp. za kalendářní měsíc 50 hodin. Př́íplatek za práci přesčas záleží na kolektivní smlouvě.

16 Dále jen ZoPD.

17 Právní úprava započítávání přestávky do pracovní doby je obdobná úpravě obsažené v zákoníku práce. V dalším se švédská právní úprava taktéž v mnohém podobá. Kupříkladu maximální rozsah pracovního úvazku je navázána taktéž na pracovní smlouvu (a př́ípadně druh práce u zaměstnavatele). Jinak řečeno, je možné mít více pracovní úvazku. U zletilých zaměstnanců nedochází ke sčítání pracovní doby v jednotlivých úvazcích.

18 Dále lze poukázat na oproti tuzemské právní úpravě podrobnější úpravu pracovní pohotovosti. Dle ust. § 6 ZoPD je možné držet pracovní pohotovost na telefonu maximálně v rozsahu 48 hodin za 4 týdny, nebo 50 hodin za kalendářní měsíc. 
Vedle základní právní úpravy přesčasové práce částečně stojí právní úprava obsažená v ust. $\S 9$ ZoPD, která upravuje výkon (přesčasové) práce $\mathrm{v}$ době mimořádných událostí (např. živelní událost atp.).

Obecné omezující pravidlo (vycházející ze směrnice 2003/88/ES) regulující úhrnný maximální rozsah výkonu práce obsahuje ust. §16 ZoPD, dle kterého výkon práce v rámci vyrovnávacího období 4 měsíců nesmí přesáhnout 48 hodin v týdnu v průměru.

\section{ZMĚNA PRÁVNÍ ÚPRAVY DOVOLENÉ}

Aktuálně již opakovaně navrženým novelizačním bodem ve vztahu k zákoníku práce, ohledně nějž bezezbytku platí, že nejsou dány důvody a splněny podmínky pro změnu právní úpravy, je komplexní změna právní úpravy dovolené. S ohledem na dobu, po níž se stávající systém dovolené v podstatě bezproblémově uplatňuje, s ohledem na náklady, které s sebou změna ponese (softwarové vybavení, školení zaměstnanců, spory vzniklé z nové právní úpravy atp.), z nichž mnohé budou plynout zejména ze složitosti nové úpravy, stejně jako s ohledem na vy̌šśí administrativní zátěž, kterou nový systém skrývá, by byla taková změna možná pouze na základě důsledné a podrobné analýzy stávajícího stavu, z níž by vyplynulo, že uplatňováním stávajícího sytému dochází k zásadním a nikoli výjimečným nespravedlnostem. Taková analýza však zjevně provedena nebyla, nebo to alespoň $\mathrm{z}$ důvodové zprávy ani $\mathrm{k}$ jednomu $\mathrm{z}$ návrhů neplyne. $\mathrm{Z}$ dosavadních poznatek $\mathrm{z}$ advokátní praxe naopak plyne, že zaměstnanci ani zaměstnavatelé stávající systém výpočtu dovolené nevnímají jako problematický či nějak hrubě nespravedlivý.

I přes tuto zásadní výhradu, která by v podstatě sama stačila $\mathrm{k}$ odmítnutí celé navržené koncepce, v krátkosti několik poznámek.

Institut dovolené, i v kontextu evropské právní úpravy, která má být zdejší legislativou provedena, má být vystaven na základě dříve provedených zdravotních analýz tak, aby zaměstnanec čerpal dovolenou nejméně v rozsahu 4 (pracovních) týdnů v roce, ideálně v celku. Nepřetržitý odpočinek v rozsahu 4 týdnů za rok by měl vést $\mathrm{k}$ regeneraci pracovní síly zaměstnance a $\mathrm{k}$ jeho dlouhodobě dobrému zdravotnímu stavu. Není-li možné čerpat 4 týdny v celku, měla by být dovolená čerpána tak, že alespoň jedna její část činí 2 týdny v celku. Je nicméně možné ujednat si i kratší dobu čerpání dovolené. Nejkratší část dovolené činí půlden.

Dikce stávající právní úpravy vede k praxi, že dovolená nebývá čerpána v kratších časových úsecích, nežli je jeden den. Často bývá čerpána po jednotlivých týdnech. Takto bývají zpravidla vyčerpány dva až tři týdny. Zbytek je čerpán po jednotlivých dnech.

I takové nakládání s dovolenou, kdy je, byt’ z části, čerpána po dnech, je de facto $\mathrm{v}$ rozporu se smyslem institutu. Byt navrhovaná právní úprava nepředpokládá, že by bylo možné čerpat dovolenou po hodinách, nelze se vyhnout obavám, že v praxi nebude čtena jinak, což (byt' se bude jednat o postup v rozporu se zákonem) povede ještě k větší atomizaci čerpání dovolené. To není rozhodně žádoucí.

Dále, nově navržená koncepce předpokládá důsledné vedení evidence pracovní doby, když operuje s odpracovanými týdenními pracovními dobami. Takový požadavek je v kontextu základních povinností zaměstnavatele rozumný. V praxi však 
může způsobit problémy, nebot' řada zaměstnavatelů v tomto směru nepostupuje úplně svědomitě. Tento argument však pro přijetí či odmítnutí nové koncepce nemůže být relevantní. Pouze potvrzuje, že při formulování institutu nebylo př́liš hleděno na poznatky z aplikační praxe.

Co však částečně relevantní být může, je, že v rámci nové koncepce nebude možné zjistit nárok na dovolenou obratem (bude potřeba znát přesný počet odpracovaných hodin), což může být problematické např́íklad při vyjednávání o skončení pracovního poměru, které vede vedoucí zaměstnanec se zaměstnancem.

Není zřejmé, proč se $\mathrm{v}$ nové koncepci neoperuje s celým kalendárním rokem, ale s 52 týdny. Kalendářní rok má 52 týdnů a 2 dny, př́p. 1 den.

$\mathrm{K}$ diskusi je jistě i nově navržená právní úprava krácení dovolené. $\mathrm{V}$ této souvislosti je třeba vidět zejména fakt, že zaměstnavatelé využívají institut krácení dovolené primárně a v podstatě výlučně při skončení pracovního poměru okamžitým zrušením pro zvlášt' hrubé porušení pracovní kázně. V těchto případech se nezdá stávající sankční podoba institutu nepřiměřená.

Stranou by nemělo zůstat ani šiřeji pojaté posuzování důležitých osobních překážek v práci za výkon práce pro účely výpočtu dovolené, zejména jde-li o ženy čerpající mateřkou a rodičovskou dovolenou. V této souvislosti si lze položit otázku, zda opatření na jejich podporu, jak je nastaveno ve vztahu k právní úpravě dovolené a ve vztahu $\mathrm{k}$ návratům z překážek $\mathrm{v}$ práci (ust. § 206a ZPr ve znění novely), jde-li o návrat z rodičovské dovolené, nemůže mít opačný efekt. Konkrétně, zda místo větší ochrany této skupiny zaměstnanců nemůže způsobit ještě složitější pozici zejména žen v plodném věku na trhu práce.

A konečně $\mathrm{k}$ otázce rovnosti a nedokonalosti stávajícího sytému. Žádný právní institut není a pravděpodobně nikdy nebude dokonalý, tedy nebude řešit všechny př́pady stejně a nebude generovat pro všechny stejné podmínky a důsledky. Pod tímto úhlem pohledu je důvod pro změnu institutu pouze tehdy, působí-li nedůvodné (a závažné) nespravedlnosti nebo nabízí-li se jiné (nové) řešení, které je spravedlivější (z hlediska aktuálního uspořádání hodnot) a lze u něj důvodně předpokládat, že jím přivozené pozitivní důsledky převáží pravděpodobné náklady a jiné negativní projevy na straně adresátů, bude-li zavedeno. Tento předpoklad zde však naplněn není.

Navíc navrhovaný model zdaleka není bez chyby. I zde si lze dost dobře představit př́pady, kdy vzniknou nerovnosti, resp. př́ípady, které nebudou odpovídat povaze institutu.

Nabízí se kupříkladu situace, kdy bude osamělá zaměstnankyně (ust. § 350 odst. 1 ZPr) pečující o dítě do 15 let věku pracovat na pracovní úvazek v rozsahu stanovené týdenní pracovní doby v rovnoměrném rozvržení pracovní doby. Tento režim se vůči ní bude uplatňovat 39 týdnů od počátku kalendářního roku. Po tuto dobu nebude čerpat žádnou dovolenou, dovolenou má plánovánu až v poslední čtvrtině roku. Zaměstnankyně si požádá v souvislosti s péčí o dítě o zkrácení pracovního úvazku na 0,25 násobek stanovené týdenní pracovní doby.

Za této situace zaměstnankyni vznikl za první 3/4 roku (ust. § 213 odst. 4 ZPr ve znění novely) nárok na dovolenou v rozsahu 120 hodin. Ve zbytku roku jí vznikne nárok na dovolenou v rozsahu 10 hodin. Celkový nárok na dovolenou tudíž bude činit 
130 hodin. S ohledem na to, že zaměstnankyně pracuje nově v režimu 10 hodinového pracovního týdne, činí její celkový nárok (jelikož navrhovaný systém nezná žádné korekční nástroje) na dovolenou ke konci roku 13 týdnů z hlediska režimu nově určeného rozsahu pracovního úvazku.

Takový důsledek zjevně neodpovídá smyslu institutu, který v této části váže na organizační funkci pracovního práva.

Navrhovaný způsob určování rozsahu nároku na dovolenou je (minimálně v Evropě) netypický. Jen několik př́kladů, nezná ho ani Slovenský zákon č. 311/2001 Z. z., zákoník práce, ani Rakouský zákon č. 390/1976 BGBI, o sjednocení práva na dovolenou a o nároku na pracovní volno, a ani Švédský zákon č. 1977: 480 SFS o dovolené. 19, 20

Právní úpravy jsou možná až překvapivě rozdílné, když některé hovoří o nároku ve dnech, některé v týdnech, některé přiznávají nárok na dovolenou v různém rozsahu dle věku či doby trvání pracovního poměru, mají rozdílné momenty a podmínky vzniku nároku, stejně tak jako pravidla o tom, zda, $v$ jakém rozsahu a kdy má dovolená povahu placeného volna atp. Žádná z nich však nejde navrhovanou cestou přepočtu přes hodiny (a naplněných stanovených týdenních pracovních dob), která se, jak bylo uvedeno shora, příčí účelu právní úpravy; žádná taktéž neobsahuje tak složitý výpočtový vzorec zohledňující mj. skutečně odpracované hodiny atp.

Kupříkladu Švédská právní úprava předepisuje 25 dní pracovního volna ročně, přičemž však stanoví v ust. $\S 7$ ZoD klíč, jehož prostřednictvím se vypočte, kolik z dní pracovního volna bude placených. Rozhodným obdobím pro zjišt'ování nároku na dovolenou je pak období od 1 . dubna do 31. března následujícího kalendářního roku. Pokud pracovní poměr vznikne, resp. zaměstnanec započne s výkonem práce po 31 . srpnu, má nárok pouze na 5 dní dovolené za období od vzniku pracovního poměru do konce období podle předchozí věty. Při zaměstnání kratším 3 měsíců právo na dovolenou nevzniká, zaměstnanci však náleží finanční kompenzace odpovídající počtu dní placené dovolené, na které by mu v pracovním poměru na delší dobu za takové období vznikl nárok.

Dovolená se poskytuje zásadně $\mathrm{v}$ celých kalendářních dnech, přičemž v červnu až v srpnu by měli být poskytnuty 4 týdny dovolené v celku; to neplatí, žádají-li si to důležité důvody. Jeden týden dovolené je možné převést do následujícího roku, resp. převádět jej spolu s dalšími „uspořenými“ dny po dobu dalších 5 let; smyslem je, aby si zaměstnanec mohl za každých 5 let vybrat 10 týdnů dovolené vcelku.

Švédská právní úprava dovolené a spolu s ní i právní úprava pracovní doby nabízí širokou možnost reagovat prostřednictvím kolektivních smluv.

19 Dále jen ZoD.

20 Tento „př́iběh“ je až nápadně podobný právní úpravě okamžitého zrušení základního pracovněprávního vztahu zákonným zástupcem nezletilého zaměstnance, jak byla od 1. ledna 2014 do 27. února 2017 obsažena v zákoníku práce a v občanském zákoníku, než zákonodárce zjistil, co tvrdila většina odborné veřejnosti od samého počátku (viz například MORÁVEK, J. Skončení pracovního poměru - aspekty NOZ. Acta Iuridica Olomucensia, vědecký časopis právnický, sv. 8, 2013, s. 43-56), tedy že taková úprava je nesmyslná a nepoužitelná a fakt, že jí má pouze Finsko (jak vyplývalo z důvodové zprávy - viz Parlament České republiky, Poslanecká sněmovna 2010-2013, tisk 362/0), kdežto ostatní dvě řešení mají např́iklad Belgie, Estonsko, Litva, Mad'arsko, Německo, Nizozemsko, Rusko, Švýcarsko, není projevem toho, že pracovněprávní legislativy ve Finsku by byla nejpokrokovější a nevyspělejší, nýbrž bud’to je zde historická příčina a jde o projev tradice, nebo se jedná o nějaký druh excesu mající jinou příčinu. 
Kupříkladu závodní kolektivní smlouva o pracovní době pro úsek výroby (lokální kolektivní smlouva) platná od 1. června 2018 mezi Závodním klubem odborového svazu IF Metall (odborový svaz KOVO) a společností Volvo Cars, pro technické zaměstnance, zavádí jako jeden z řady institutů osobní banku pracovní doby zaměstnance. Kolektivní smlouva předpokládá u zaměstnanců, kteří nevykonávají práci v nočních směnách, celkový počet 2080 pracovních hodin za rok s tím, že pracovní úvazek zaměstnance činí 43 hodin týdně. Tři hodiny z týdenního úvazku, označené jako více čas, nejsou považovány za přesčasovou práci. Důvodem je, že 3 hodiny a 27 minut týdně z odpracované pracovní doby (43 hodin) se převádí do osobní banky zaměstnance na jeho osobní konto. Kumulace pracovní doby na osobním kontu není časově omezena. Nároky zaměstnance se nepromlčují. V důsledku působení jiné z kolektivních smluv však zaměstnavatel může v říjnu každého kalendářního roku, přesahuje-li zůstatek zkumulovaných hodin zaměstnance více jak 250 , zredukovat počet až na 250 hodin spolu $\mathrm{s}$ tím, že zaměstnanci ve vztahu k přepočetným hodinám svědčí právo (a) na proplacení zkumulovaného přepočetného času, (b) na placené (náhradní) volno v rozsahu přepočetných hodin, (c) převedení hodin/finanční kompenzace do penzijního fondu zaměstnance. V této souvislosti lze jen doplnit, že tohoto práva zaměstnavatel od roku 2007 využil jen jedenkrát.

Kumulovanou pracovní dobu na osobním kontu je možné vybrat trojím způsobem. Zaměstnanec si může jednak vybrat placené pracovní volno v jím určeném rozsahu (včetně možné kombinace s jinak neplacenou dovolenou - finanční zajištění po dobu pracovního volna z titulu dovolené se poskytne z konta zaměstnance), jednak je možné v zaměstnancem určeném rozsahu poskytnout přímou finanční náhradu bez pracovního volna, jednak je možné peněžní prostředky odpovídající náhradě, kterou by zaměstnanec obdržel, převést do závodního penzijního fondu. Náhrada mzdy v době pracovního volna, stejně jako finanční kompenzace za „prodej“ pracovních hodin, se poskytuje ve výši průměrné mzdy zaměstnance $\mathrm{v}$ době čerpání/prodeje bez ohledu na to, o pracovní čas, z jakého období se jedná. To lze (z hlediska zaměstnance) hodnotit pozitivně, nebot' při dlouhodobé kumulaci bude hodina času připsaná na osobní konto v roce 2000 proplacena mzdou k okamžiku čerpání, tedy na př́klad v roce 2018, která bude zpravidla větší, při změně pozice atp. není vyloučeno, že dokonce násobně.

\section{VYBRANÉ OTÁZKY SKONČENÍ PRACOVNÍHO POMĚRU}

Jedním z pravidelných témat $\mathrm{v}$ diskusích o novelizaci pracovněprávních prredpisů je institutu, který se označuje jako „výpovéd” bez výpovědního důvodu“ nebo „výpověd” bez dưvodu“. Aktuálně připravovaná novela zákoníku práce (prozatím) tuto otázku neřeší. V minulosti se však v rámci různých návrhů tyto tendence objevily. Měly různou podobu a pravidelně trpěly různou mírou nekoncepčnosti.

$\mathrm{V}$ prvé řadě si lze jen velice těžko představit, že by $\mathrm{v}$ rámci zdejší právní kultury a kontinentálního systému práva, mj. v návaznosti na tradici relativně silné právní ochrany postavení zaměstnance a koncept sociálního státu obecně, mohla existovat skutečná výpověd’ z pracovního poměru ze strany zaměstnavatele bez uvedení důvodu, 
resp. bez skutečného materiálního důvodu, tedy shodný institut, který zákoník práce zná ve směru k zaměstnanci. Vyloučíme-li tuto možnost, nabízí se dvě situace, která lze vztáhnout pod shora uvedený pojem.

Bud'to se může jednat o institut vyplacení/vykoupení ze zaměstnání v pozici, kdy právní úprava nabízí zaměstnavateli možnost se zaměstnancem jednostranně rozvázat pracovní poměr bez specifikace kauzálního důvodu, kterou však podmiňuje vyplacením určité částky odchodného, jehož výše zpravidla představuje několikanásobek průměrného měsíčního výdělku zaměstnance; počet průměrných výdělků se může odvíjet mj. od doby trvání pracovního poměru zaměstnance k zaměstnavateli. Pro upřesnění lze doplnit, že vykoupením ze zaměstnání, resp. vyplacením ze zaměstnání může rozumět taktéž situaci, kdy je pracovní poměr (z jedné nebo z druhé strany) skončen jednostranným právním jednáním $\mathrm{s}$ výpovědní dobou, přičemž vypovězená strana pracovního poměru nemá zájem, aby pracovněprávní vztah přetrval po celou výpovědní dobu. Pro tyto př́ípady jí pak zákon nabízí možnost skončit pracovní poměr předčasně, tj. před uplynutím výpovědní doby, při zaplacení předepsané peněžité částky.

Vedle toho (avšak nepřesně) bývá za druhou variantou výpovědi „,bez důvodu“, která se mj. objevila $\mathrm{v}$ jednom $\mathrm{z}$ pozměňovacích návrhů $\mathrm{k}$ loňské „koncepční“ novele zákoníku práce, označována výpověd' z pracovního poměru ze strany zaměstnavatele při naplnění obecné skutkové podstaty/výpovědního důvodu formulovaného zhruba tak, že „po zaměstnavateli již nelze spravedlivě požadovat, aby zaměstnance dále zaměstnáva$l^{\prime \prime} .{ }^{21}$ Konkrétně, předmětem pozměňovacího návrhu Zbyňka Stanjury k loňské novele zákoníku práce bylo doplnění ust. § 52 ZPr ve smyslu, že mimo již existující důvody by zaměstnavatel mohl se zaměstnancem skončit pracovní poměr výpovědí také tehdy, nebylo-li by již po zaměstnavateli spravedlivé požadovat, aby zaměstnance nadále zaměstnával; jde de facto o přepis pravidelně se objevující formule v rozhodnutí Nejvyššího soudu České republiky, která se vztahuje ke skončení pracovního poměru pro porušení pracovní kázně (povinnosti vyplývající z právních předpisů vztahujících se k zaměstnancem vykonávané práci).

Je zjevné, že prezentace takového řešení jako skončení pracovního poměru „bez důvodu“ je pouze politickou proklamací, nebot' nemá-li být po zaměstnavateli spravedlivé požadovat, aby zaměstnance dále zaměstnával, musí existovat legální a legitimní důvod (převažující zájem na stabilitě pracovního poměru). Legálním a legitimním důvodem může být, že zaměstnanec není zdravotně způsobilý k práci, či že zaměstnavatel ruší provoz, nebo jej přesouvá mimo místo výkonu práce zaměstnance, anebo že v důsledku technologických či jiných změn organizační povahy odpadne potřeba zaměstnancovi práce, př́p. že zaměstnanec nesplňuje předpoklady plynoucí z právních předpisů ve vztahu $\mathrm{k}$ vykonávané práci, či snad že zaměstnanec porušuje své pracovněprávní povinnosti $\mathrm{v}$ určité míře a intenzitě. Vezmeme-li v patrnost, že právní úprava $\mathrm{v}$ této části představuje mj. částečně provedení práva svobodnou volbu povolání a současně, že je zde (mj. i celospolečenský) zájem na určité míře stability pracovněprávních vztahů,

21 Předmětnou úpravu, spolu s několika dalšími souvisejícími s právní úpravou skončení pracovního poměru, navrhl poslanec Zbyněk Stanjura dne 1. března 2017 při projednávání návrhu zákona ve druhém čtení. 
pak těžko budeme hledat jiný důvodem mimo právě uvedené, tedy výpovědní důvody, které již zákon zná.

I přes uvedené je zde však důvod se naznačenou konstrukcí, tedy právem zaměstnavatele se zaměstnancem skončit pracovní poměr výpovědí v momentě, kdy po zaměstnavateli nelze spravedlivě požadovat, aby zaměstnance dále zaměstnával, zabývat. Důvodem je snad až určitá obřadnost, kterou stávající právní úprava předpokládá pro platnost skončení pracovního poměru - zákonný důvod, specifikace důvodu, využití důvodu $\mathrm{v}$ zákonné lhůtě, $\mathrm{v}$ některých př́padech předchozí písemné upozornění konkrétního obsahu atd. ${ }^{22}$ V kontextu judikatury Nejvyššího soudu České republiky nikoli výjimečně bývá i přes legitimní důvod pro skončení pracovního poměru právní jednání neplatné kvůli nenaplnění některé z předepsaných formalit.

V tomto kontextu se tudíž zdá vhodnějši úprava, kterou zná kupř́ikladu švédský zákon č. 1982: 80 SFS o ochraně zaměstnanců..$^{23}$ Zákon předpokládá kauzální důvody (§ 9) pouze $\mathrm{v}$ případě, kdy dochází $\mathrm{k}$ okamžitému zrušení pracovního poměru. Jinak platí, že pracovní poměr je možné vypovědět, existuje-li objektivní a legitimní důvod, aniž by se konkrétně stanovilo, co takový objektivní důvod znamená; vyjma nadbytečnosti se o každém skončení z objektivního důvodu jedná s odborovou organizací. V kolektivní smlouvě lze důvody př́ípadně taktéž specifikovat.

Určitá volnost $\mathrm{v}$ tomto směru je kompenzována délkou výpovědní doby. Minimální délka výpovědní doby činí 1 měsíc. $\mathrm{V}$ závislosti na době trvání pracovního poměru k zaměstnavateli se však prodlužuje, když při zaměstnání trvajícím

- nejméně 2 roky a ne více jak 4 roky činí 2 měsíce;

- nejméně 4 roky a ne více jak 6 let činí 3 měsíce;

- nejméně 6 let a ne více jak 8 let činí 4 měsíce;

- nejméně 8 let a ne více jak 10 let činí 5 měsícư;

- nejméně na 10 let činí 6 měsíce.

Z hlediska zdejšího pojímání není bez zajímavosti, že během výpovědní doby může zaměstnanec vykonávat práci pro jiného zaměstnavatele. Odměna/náhrada od původního zaměstnavatele se přitom snižuje o to, co zaměstnanec utrží při práci pro jiného zaměstnavatele $\mathrm{v}$ rámci výpovědní doby.

Právní úprava obsažená v ZoOZ však může být inspirativní i v jiných ohledech. Jde-li o skončení pracovního poměru, zná zákon kupř́kladu mechanismus, jímž se určuje, je-li více zaměstnanců nadbytečných, ten, se kterým bude skončen pracovní poměr. Do počtu 10 zaměstnanců u zaměstnavatele si může zaměstnavatel volit sám. Jinak, není-li ujednáno něco jiného s odborovou organizací, je rozhodný den nástupu do zaměstnání nadbytečný je předně ten, kdo nastoupil nejpozději.

Zákon zná taktéž nabídkovou povinnost jak při skončení pracovního poměru, tak v době (až 9 měsíců) po skončení pracovního poměru (projeví-li zaměstnanec při skončení pracovního poměru zájem o pozdější předpokládání nabídek pracovního uplatně-

$22 \mathrm{~K}$ tomuto srov. MORÁVEK, J. Skončení pracovního poměru - mancipace v pracovním právu? In: BĚLOVSKÝ, P. (ed.). Caro amico - 60 kapitol pro Michala Skřejpka aneb Římské právo napříc staletími. Praha: Auditorium. 2017.

23 Dále jen $\mathrm{ZoOZ}$. 
ní). V př́ípadě pracovních poměrů na dobu určitou a sezónních prací se lhůta obnovuje po každém skončení pracovního poměru.

Právní úprava se však liší i v jiných aspektech. Kupř́ikladu dle ust. § 6 ZoOZ je předepsána délka zkušební doby na 6 měsíců. Ustanovení $\S 5$ a $\S 5$ upravuje pracovní poměry na dobu určitou, přičemž nepředepisuje žádný maximální počet opakování či maximální délku trvání pracovního poměru na dobu určitou. Stanoví nicméně podmínky, za kterých se pracovní poměr na dobu určitou přerodí v pracovní poměr na dobu neurčitou.

Z hlediska zdejší právní kultury lze nicméně v zákoně identifikovat i momenty, které jsou zjevně nekompatibilní a nepoužitelné, jako je zvláštní úprava pro zaměstnance starší 67 let, tedy pro zaměstnance důchodového věku; u těchto zaměstnanců kupříkladu nedochází $\mathrm{k}$ automatickému přerodu pracovního poměru z doby určité na dobu neurčitou atp.

Nejsou to však jen délka výpovědní doby, vykoupení ze zaměstnání a méně formální nároky na právní jednání, jímž se pracovní poměr končí. Podobně by bylo možné v kontextu aplikační praxe zejména vyšších soudů, které v drtivé většině př́ípadů rozhodují pouze podle listin/obsahu spisu, aniž by měly kontext skutečného vztahu stran pracovního poměru a učinili si (i přes formální podklad tvrzení) představu o věrohodnosti účastníků ř́zení, stejně tak jako v kontextu obecné tendence soudů spočívající v zaměřování se primárně na formální aspekt věci, aniž by byl reflektován konečný a primární účel práva, jímž je dosažení spravedlnosti, formulovat závěr, že zdejší právní úpravě schází výslovné zakotvení institutu dodatečného (sociálního) ospravedlnění výpovědi/ skončení pracovního poměru, který zná např́íklad německá právní úprava. ${ }^{24}$

Konkrétněji, právní úprava Spolkové republiky Německo v kontextu principu spravedlnosti, jako konečného účelu objektivního práva, a zásady zákazu zneužití objektivního práva, vychází z předpokladu, že bude-li po skončení pracovního poměru prokázán důvod/skutek (existující v době trvání pracovního poměru), který by jinak mohl ospravedlnit skončení pracovního poměru, je třeba $\mathrm{k}$ němu přihlédnout $\mathrm{v}$ př́padném sporu zaměstnance a zaměstnavatele o platnosti/neplatnosti právního jednání, jímž se pracovní poměr skončil. Důvodem je mj. skutečnost, že by nedávalo dobrý smysl, aby kvůli nejistotě stran platnosti skončení pracovního poměru, které je předmětem soudního přezkumu, byl zaměstnavatel zbaven práva skončit se zaměstnancem pracovní poměr $\mathrm{z}$ tohoto dodatečného důvodu.

Podstatou institutu je tzv. sociální ospravedlnění skončení pracovního poměru (výpovědi) - zaměstnavatel má mít právo se zaměstnancem skončit pracovní poměr tehdy, je-li to s přihlédnutím ke všem okolnostem známým při projevu vůle směřujícího ke skončení pracovního poměru, stejně tak jako ke všem okolnostem, které vyjdou dodatečně najevo a podporují záměr zaměstnavateli, legitimní.

Německá právní úprava (viz zejména Kündigungsschutzgesetz a Betriebsverfassungsgesetz) tak umožňuje v soudním sporu zaměstnance a zaměstnavatele zohlednit i důvod pro skončení pracovního poměru existující v době skončení pracovního pomě-

24 Srov. například BADER, P. - ETZEL, G. et al. Gemeinschaftskommentar zum Kündigungsschutzgesetz und zu sonstigen kündigungsschutzrechtlichen Vorschriften. 7. Aufl. München: Luchterhand, 2004, LVIII, 3298 s. p. ISBN 3-472-05773-4, s. 83-84. 
ru, aniž by o něm zaměstnavatel skutečně věděl. Podstatnou je, v návaznosti na konečný účel objektivního práva, jak ve zdejším právním prostředí (právním řádu), tak v právním řádu Německa, sociální ospravedlnitelnost skončení pracovního poměru (spravedlnost/legitimita skončení pracovního poměru) - při rozhodování o platnosti skončení pracovního poměru, byla-li již projevena vůle zaměstnavatele směřující ke skončení pracovního poměru, je rozhodný objektivní stav, tedy objektivní existence důvodů pro skončení pracovního poměru, nikoliv subjektivní vědomost na straně zaměstnavatele.

Jinak řečeno, důležité pro posouzení, zda je skončení pracovního poměru sociálně ospravedlnitelné (po právu), je v tomto kontextu objektivní existence výpovědního důvodu v době podání výpovědi, nikoliv subjektivní vědomost zaměstnavatele. V důsledku toho může tudíž být důvod výpovědi ještě i de facto dodatečně změněn - skončení pracovního poměru může být kvalifikováno jako platné, byt' by původní důvod zahrnutý do právního jednání zaměstnavatele sám o sobě neobstál, pokud dodatečně v řízení zjištěný a prokázaný důvod, který není do právního jednání zahrnut, nicméně existoval v době trvání pracovního poměru, skončení pracovního poměru odůvodňuje (takový důvod je dostatečný), a to i kdyby se o něm zaměstnavatel dozvěděl až po skončení pracovního poměru (tř̌eba i až v průběhu ř́zení).

\section{ZÁVĚR}

Stávající právní úprava pracovněprávních vztahů v širokém smyslu slova má několik slabých momentů. Ty dle všeho plynou mj. z nedostatečné reflexe hospodár̆ského a technického vývoje, což má za důsledek mj. jistou zkostnatělost úpravy, která neumožňuje reagovat na nové potřeby a trendy aplikační praxe. Uvedené platí přirozeně i pro legislativu ve smyslu tvorby zákonodárství, kde, zdá se, schází potřebný kontakt s praxí. Tento stav, spolu s v podstatě zcela disfunkční vnitřní kontrolou a s velice slabou vnější kontrolou dodržování právních pravidel, ${ }^{25,26}$ jejíž příčina spočívá v nedostatečné personální a odborné vybavenosti kontrolních orgán, zejména inspektorátů práce, to vše podpořeno nákladností a složitostí uplatnění práv soudní cestou (včetně délky řízení), ${ }^{27}$

$25 \mathrm{~K}$ počtu provedených kontrol v jednotlivých oblastech ze strany inspektorátů práce viz výroční právy Státního úřadu inspekce práce (viz <http://www.suip.cz/rocni-zpravy/>).

26 Pro právě uvedené závěry svědčí statistické údaje z výročních zpráv Státního úřadu inspekce práce, jde-li kupř́kladu o kontrolu bezpečnosti a ochrany zdraví na staveništích, kde jsou poměrně komplexní a rozsáhlé požadavky plynoucí z právních předpisů na zajištění bezpečnosti a ochrany zdraví při práci (viz <http:// www.suip.cz/rocni-zpravy/>). Úhrnný počet kontrol vykonaných inspektoráty práce za rok čítá řádově desetitisíce př́padů (v roce 2017 se jednalo kupříkladu o 24.945 kontrol, v roce 2016 pak o 26.620 kontrol - viz tiskové zprávy na stránkách Státního úřadu inspekce práce - viz http://www.suip.cz/pro-media /tiskove-zpravy/) z nichž však na oblast bezpečnosti a ochrany zdraví na staveništích bylo zaměřeno: v roce 2012 celkem 1.386; v roce 2013 celkem 1.233; v roce 2014 celkem 1.159; v roce 2015 celkem 987; v roce 2016 celkem 875 ; v roce 2017 celkem 785 .

27 Z průzkumu provedeného v roce 2016 u všech okresních a obvodních soudů vyplynulo, že celkový nápad pracovněprávních sporů na všechny okresní soudy byl 4.246 věcí v roce $2012,4.431$ věcí v roce 2013 , 4.913 věcí v roce 2014, 3.647 věcí v roce 2015 a 1.336 věcí do 31. května 2016. Srov. PICHRT, J. - ŠTEFKO, M. - MORÁVEK, J. Analýza alternativních způsobů řešení sporů v pracovněprávních vztazích. Praha: Wolters Kluwer, 2016. s. 223. V roce 1988 přitom dle dostupných informací čítal celkový roční nápad pracovněprávních sporů 26.466 př́ípadů a tvořil $14,9 \%$ z celkového soudního nápadu. Aktuálně 
nikoli nevýznamně potlačuje platnost právní regulace. Kupř́ikladu předpisy o bezpečnosti a ochraně zdraví při práci, ale i pravidla o pracovní době atp., v mnoha př́padech pro zaměstnavatele představují jen bezobsažné formule, jimž není třeba věnovat pozornost a jejich reálná váha činí asi tolik, kolik je hmotnost papíru, na kterém jsou zapsány.

Nalézt odpovídající řešení není lehké. S ohledem na významné odlišnosti v jednotlivých způsobech výkonu práce a provozech, s ohledem na mnohdy diametrálně odlišné potřeby, se nabízí uvažovat o základní rámcové regulaci na úrovni právních předpisů (primárně zákona) s tím, že v dílčích podrobnostech budou pravidla dotvořena na podnikové úrovni dohodou zaměstnavatele a zaměstnanců, resp. přesněji zástupců zaměstnanců (odborů) s přihlédnutím k potřebám př́íslušného provozu.

Aktivní působení zaměstnanců, resp. zástupců zaměstnanců na podnikové úrovni by s sebou z povahy věci neslo i posílení vnitřní kontroly, a tedy zvýšení úrovně platnosti zákonné regulace. Tento aspekt by stejně tak podpořilo jednak personální posílení (zejména z hlediska odbornosti) kontrolních orgánů a jednak dle všeho specializované pracovní soudnictví či alespoň pevná specializace soudce obdobná správnímu úseku, kdy by senát byl tvořen vedle předsedy senátu, jímž by byl soudce z povolání, nejméně jedním přísedícím vybraným z nominantů zaměstnavatelů a jedním př́sedícím vybraným z nominantů zaměstnanců. Tento systém ostatně znal již zákon č. 131/1931 Sb. a n., o pracovních soudech, dle jehož ust. § 16 ,,pracovní soud jedná a rozhoduje v senátech složených z prèedsedy nebo jeho náměstka a ze dvou prísedících, z nichž jeden jest ze skupiny zaměstnavatelů, druhý ze skupiny zaměstnancü. " Specializace, která by mohla přinést i zrychlení rrízení, však sama o sobě nestačí. Pro posílení platnosti právního řádu je stejně tak potřebná a možná potřebnější účast zástupců zaměstnanců v rámci ř́zení, konkrétně odborná podpora a pomoc v podobě zastupování. ${ }^{28}$ Stejně tak se nabízí úvaha, zda či v jaké míře by mělo být řízení v pracovních věcech podrobeno poplatkové povinnosti.

Z uvedeného se podává, že zásadní je aktivní (nikoli aktivistické) zapojení zástupců zaměstnanců (odborů) na odpovídající odborné úrovni. To se však prozatím zdá jako těžko dosažitelný cíl.

Stávající postavení odborů v České republice, včetně nízké odborové organizovanosti (přibližně $33 \%$ ), ${ }^{29}$ nezájmu o účast $\mathrm{v}$ odborech a o jejich činnost, plyne z řady faktorů.

Jedním z nejpodstatnějších je bezesporu určitá pachut', kterou nese reminiscence předlistopadové doby, kdy (de facto povinná) odborová organizovanost v Revolučním

pritom z celkového ročního soudního nápadu tvoří pracovněprávní spory již dlouhodobě (nejméně od roku 2011) méně jak $1 \%$. Tamtéž s. 6-7.

28 Z průzkumu provedeného $\mathrm{v}$ roce $2016 \mathrm{u}$ všech okresních a obvodních soudů vyplynulo, že odborové organizace zastupovali z celkového nápadu (viz předchozí poznámka) v následujícím počtu př́ípadů: rok 20124 prŕípady, rok 20133 př́ípady, rok 20145 př́ípadů, rok 20159 př́ípadů, za rok 2016 do 31. května 2016 v 1 př́ípadě. PICHRT, J. - ŠTEFKO - M., MORÁVEK, J. Analýza alternativních zpuisobů řešení sporů v pracovněprávnich vztazích. Praha: Wolters Kluwer, 2016. s. 200.

29 Srov. Bognárová, V. In: BĚLINA, M. - PICHRT, J. a kol. Pracovní právo. 7. doplněné a podstatně přepracované vydání. Praha: C. H. Beck, 2017, s. 386. 
odborovém hnutí (ROH) dosahovala bezmála $100 \%{ }^{30}$ Odmítání předlistopadových schémat, jistá dezorientace ve svobodném světě, rozvoj soukromého podnikání a malých podniků spolu se zánikem řady velkých průmyslových podniků, to vše vedlo k přetržení (byt'v době komunistické nesvobody pokřivené) zdejší tradice relativně odborové organizovanosti. Odboroví předáci (nejen té doby) dle všeho nesprávně vyhodnotili situaci. Místo vybudování odpovídajícího zázemí, tj. zejména získání potřebného lidského kapitálu, který bude schopen flexibilně reagovat a poskytovat podporu a moc $\mathrm{v}$ individuálních prŕípadech, práce se zaměstnanci v podniku a řešení jejich každodenních problémů, včetně jejich zastupování ve sporech se zaměstnavatelem, se soustředili a soustředí spiše na makroekonomické otázky a to způsobem nikoli nepodobným tomu, jak to činí politické strany a hnutí; i když je samozřejmě možná náhodou, že Richard Falbr, první předseda ČMKOS, se stal nejdříve senátorem a posléze poslancem Evropského parlamentu, že druhý předseda ČMKOS, Milan Štěch, se stal senátorem, místopředsedou Senátu a následně i předsedou Senátu Parlamentu České republiky, že třetí Předseda ČMKOS se stal poslancem Parlamentu České republiky, a že stávající předseda jmenovaného svazu si (zdá se) brousí zuby na post nejvyšší.

Ze zkušenosti lze soudit, že činnost odborových centrál má své těžiště zejména v rovině legislativy a tripartitního vyjednávání. Rovina „běžného podnikového bojiště““ je (pravděpodobně kvůli nedostatku personálních zdrojů) v pozadí. Jak jinak si vysvětlit, že odborové svazy a centrály poskytují podporu nově vznikajícím organizacím větší měrou pouze při založení, avšak v další činnosti, včetně kolektivního vyjednávání, je nechávají svému osudu. Možná je však taková představa zkreslená, nebot' závěr staví pouze na několika osobních zkušenostech. Co je však prokazatelné a hovoří pro naznačený závěr, je statistika zpracovaná v projektu Analýza alternativních způsobů řešení sporů $\mathrm{v}$ pracovněprávních vztazích. $Z$ průzkumu provedeného $\mathrm{v}$ roce $2016 \mathrm{u}$ všech okresních a obvodních soudů vyplynulo, že odborové organizace zastupovali zaměstnance z celkového nápadu pracovněprávních sporů (viz poznámka pod čarou č. 27) v následujícím počtu př́padů: rok 20124 prrípady, rok 20133 př́pady, rok 20145 případů, rok 20159 prrípadů, za rok 2016 do 31 . května 2016 v 1 prrípadě. ${ }^{31}$

Ani aktivní, efektivní a kvalifikovaná činnost odborových organizací samozřejmě není zárukou fungujícího a platného právního řádu, resp. právní regulace pracovněprávních vztahů. Může však významně přispět ke kvalitě právního prostředí, významně napomáhat a garantovat práva zaměstnanců - řada zaměstnanců nemá představu, jaká práva jim náleží a jak by je mohli uplatnit, tzn. již samotná informace o právech a způsobem jejich uplatnění je pozitivní aspekt, dalším navazujícím krokem je aktivní zastupování zaměstnanců při vyjednávání se zaměstnavatelem, jde-li o hospodářské a sociální zájmy, jakož i ve sporech o individuální nároky.

Cesta $\mathrm{k}$ takovému stavu, pokud by byla nastoupena, by byla dlouhá a musela by být nutně pozvolná.

30 Srov. GALVAS, M. K problematice reprezentace zaměstnanců v pracovním právu ČR. In: GREGOROVÁ, Z. (rec.). Sborník př́spěvků z mezinárodní vědecké konference Pracovní právo 2011 na téma Sociální dialog. Acta Universitatis Brunensis. Iuridica. sv. 406. Brno: Masarykova Univerzita. 2011. s. 12.

31 Viz PICHRT, J. - ŠTEFKO, M. - MORÁVEK, J. Analýza alternativnich způsobů řešení sporů v pracovněprávních vztazich. Praha: Wolters Kluwer, 2016, s. 200. 
Základem musí být podniková úroveň. Aby se mohla podniková úroveň stát stavebním kamenem, musí být činnost na úrovni podniku kvalifikovaná a efektivní a zástupci zaměstnanců musí být ze strany zaměstnavatele bráni vážně. Aby tomu tak bylo, musí zástupci zaměstnanců reprezentovat významný počet zaměstnanců v podniku - to jim jednak dává váhu a jednak jim umožňuje kumulovat potřebné finanční zdroje a lidský kapitál pro efektivní a kvalifikovanou činnost. Aby mělo zastupování a vyjednávání zástupců zaměstnanců a zaměstnavatele smysl, musí být o čem jednat, tedy právní úprava musí dávat odpovídající možnosti prostřednictvím dohody jmenovaných potřebným směrem a v potřebné míre posunout základní zákonná pravidla (ideálně do stavu, kdy převládá pocit win-win). Jinak řečeno, potřebná je určitá míra flexibility, která umožní po vzájemné dohodě překonat zákonnou úpravu, která by pro tyto př́ípady měla mít pouze nezbytné tvrdé kogentní jádro „kolíkující hrací pole“. Uvolňování právní regulace až do pozice uvedené $\mathrm{v}$ předchozí větě by nutně muselo být pozvolné dle míry kvalifikovanosti a kvality zástupců zaměstnanců, nebot' konečná podobě dispozitivní úpravy s minimálním tvrdým jádrem odpovídá stavu kvalifikovaných, kvalitních a efektivních zástupců zaměstnanců podpořených veřejnosprávní kontrolou a fungujícím soudním systémem umožňujícím v rozumném časovém horizontu se domoci svých individuálních nároků; jedno (veřejnosprávní kontrola) i druhé (soudní ochrana), pokud hovoříme o zajištění odpovídající funkčnosti systému a skutečné platnosti právního řádu, taktéž nemohou zůstat bez změny, zejména jde-li o personální vybavenost.

Těžko nahraditelným momentem určujícím míru odborové organizovanosti je tradice. Ta však, jak bylo uvedeno shora, byla přetržena. Cestou, jak jinak motivovat $\mathrm{k}$ většímu zájmu o své zájmy a práva, který může vést $\mathrm{k}$ sdružování do spolků, resp. odborových organizací, je flexibilita navázaná právě na sdružovací právo. Žádoucího stavu by bylo možné docílit změnou zdejšího modelu při určené inspiraci ve švédské právní úpravě.

Konkrétněji, ve Švédsku je možné, aby na jednom pracovišti působilo více odborových organizací a bylo sjednáno více kolektivních smluv, přičemž např́ílad dle $\S 2$ ZoRD či § 2a ZoD platí, že kolektivní smlouva se uplatní na zaměstnance, kteří jsou odborově organizováni v odborové organizaci, která kolektivní smlouvu sjednala, přičemž záleží na rozhodnutí zaměstnavatele, zda obsah takové kolektivní smlouvy uplatní i vůči ostatním zaměstnancům. Takové legislativní opatření by umožnilo eliminovat stávající černé pasažéry, tedy zaměstnance, kteří těží z výhod kolektivní smlouvy ujednané na pracovišti odborovou organizací, aniž by byli jejími členy a jakkoli aktivně se zajímali a zasloužili o ochranu svých hospodářských a sociálních zájmů u zaměstnavatele.

Naznačené řešení není jistě jediné možné. Jsou i jiná. Některá mohou být i lepší. Změny zažitých paradigmat tohoto charakteru si žádají čas a stabilitu. At' již bude zvoleno kteréhokoli z nich, bude třeba „držet směr“ a při prvním náznaku problémů či př̀i změně politické reprezentace ihned neměnit cíle a směřování. Možné jsou jen drobné korekce kurzu.

JUDr. Jakub Morávek, Ph.D.

Právnická fakulta Univerzity Karlovy moravek@prf.cuni.cz 